\title{
Occurrence of swan hybrids around the Baltic Sea - an outcome of range expansions?
}

\author{
Förekomst av svanhybrider omkring Östersjön - ett resultat av utvidgade \\ utbredningsområden?
}

HAKON KAMPE-PERSSON \& DMITRIJS BOIKO

\begin{abstract}
Spectacular increases in range and numbers of some swan and goose species around the Baltic Sea have resulted in more contacts between species and facilitated mixed breeding. Records of mixed breeding and observations during the non-breeding season of mixed families, mixed pairs and hybrids in which at least one of the parent species was a swan were compiled for Sweden, Finland, Leningrad and Kaliningrad Regions of Russia, Estonia, Latvia, Lithuania, Poland, Germany and Denmark. There were twelve records of mixed breeding, nine of Mute Swan $\times$ Whooper Swan and one each of Mute Swan $\times$ Greylag Goose, Mute Swan $\times$ Greater Canada

Goose and Whooper Swan $\times$ Bewick's Swan. Excluding the two cases involving a goose and two cases involving swans with captive background, there were eight breeding records in the wild. Seven of these can be explained by range expansions. The exception was a case where the identification of the male was unsure.

Hakon Kampe-Persson, Pulmaṇi, Glūdas pagasts, Jelgavas novads, LV-3040, Latvia.

E-mail: kampepersson@hotmail.com.

Dmitrijs Boiko, Natural History Museum of Latvia, Kr. Barona iela 4, Riga, LV-1050, Latvia.
\end{abstract}

Received 5 March 2011, Accepted 17 March 2011, Editor: S. Svensson

\section{Introduction}

The last half century has witnessed spectacular increases in breeding range and numbers of some swan and goose species around the Baltic Sea. While having numbered only some tens of pairs and been limited to northernmost Sweden and Finland in the early 1950s, the Whooper Swan Cygnus cygnus nowadays breeds in all countries and regions bordering the Baltic Sea, and the total population today numbers about 10,000 pairs (for references, see Boiko \& Kampe-Persson 2010). From a stronghold in south-eastern Sweden, the Greater Canada Goose Branta canadensis population developed in a similar way as the Whooper Swan population, though not breeding in the Baltic States or westernmost Russia, and it increased from 150 pairs in 1960 (Fog 1973) to 23,000-30,000 pairs in 2009 (Kampe-Persson 2010). Also the Greylag Goose Anser anser has shown large increase in numbers and range during the last 50 years (Kampe-Persson 2002), while the increase in numbers and range has been less pronounced in the Mute Swan Cygnus olor (Wieloch et al. 2004). The Barnacle Goose
Branta leucopsis and the Bewick's Swan Cygnus columbianus bewickii, on the other hand, started to breed around the Baltic Sea first in the 1950s and in the 1990s, respectively (Stratford 1999, Kurlavičius 2006, Kampe-Persson 2010).

These range expansions have resulted in more contacts between birds of related species, which in turn has facilitated mixed breeding. Hybridisation in Anatidae is much more common than in other avian groups. Hybridisation is not unusual among captive waterfowl, even between distantly related species, and it is reasonably common in the wild. Occurrence of goose hybrids in Germany and Sweden has recently been reported (Randler 2000, Kampe-Persson \& Lerner 2007), wherefore goose hybrids will be left out in this compilation.

Hybrids among swans are very rare (Brazil 2003). The three species naturally occurring in Europe have been reported to hybridise with the following number of species (Scherer \& Hilsberg 1982): Mute Swan (10), Whooper Swan (7) and Bewick's Swan (4), of which Mute Swan $\times$ Whooper Swan, Mute Swan $\times$ Black Swan Cygnus atratus, Mute Swan $\times$ Greylag Goose, Mute 
Swan $\times$ Greater Canada Goose, Whooper Swan $\times$ Whistling Swan Cygnus columbianus columbianus and Bewick's Swan $\times$ Whistling Swan have been recorded in the wild (McCarthy 2006). As there are no genetic or behavioural obstacles of successful mixed breeding of Mute Swan and Whooper Swan (Mathiasson 1980b), that combination would be the most likely of these six around the Baltic Sea.

Also the origin of the birds must be taken into consideration, because birds of captive origin are more likely to hybridise than wild ones (Randler 2000). The Greater Canada Goose was deliberately introduced for hunting purposes and translocations extended the breeding range (Andersson et al. 1999). The restoration of the former breeding range of the Greylag Goose was aided by local introductions, especially in Germany and Sweden (KampePersson 2002). The Barnacle Goose population in the Baltic Sea region is most likely the result of releases and escapes from captivity (Kampe-Persson 2010). Also the spread of the Whooper Swan was assisted by introductions, for instance in the Swedish provinces of Jämtland and Hälsingland (Svensson et al. 1999).

The aim of this study was to document the occurrence of swan hybrids around the Baltic Sea, and to determine to which degree this occurrence could be related to range expansions of the different species.

\section{Material and methods}

The study area was comprised of Sweden, Finland, Leningrad and Kaliningrad Regions of Russia, Estonia, Latvia, Lithuania, Poland, Germany and Denmark. For this area, the aim was to compile a list of breeding records and observations of mixed pairs, mixed families and hybrids, in which at least one of the parent species was a swan. The compilation was guided by the fact that information about hybrids often is found in regional and local magazines, if the observations are published at all (see Mathiasson 1992).

Members of an international net-work of "swan people", all regional report committees in Sweden, and a number of local experts as well, were contacted and kindly asked to help in gathering observations and literature. The open Swedish database Report System for Birds (a part of the Species Gateway; www.artportalen.se) was checked for observations made up to 2010 (last checked 15 March 2011) and most Swedish national, regional and local bird magazines were checked up to the last issue in 2010.

For unpublished observations obtained from the
Report System for Birds and the regional report committees in Sweden, or made by the authors, only the name(s) of the observer(s) was/were given.

\section{Results}

Breeding of mixed pairs have mainly been recorded in Sweden and Poland, while most observations of hybrids were done in Sweden (Table 1). Finland, Estonia and Leningrad and Kaliningrad Regions, on the other hand, lack both breeding records and observations of mixed pairs, mixed families and hybrids.

\section{Mute Swan $\times$ Whooper Swan.}

The first successful breeding occurred at an unknown site in south Sweden. The breeding was revealed when the Whooper Swan male turned up in Pildammsparken in the city of Malmö, from where it had escaped, together with one hybrid in the autumn of 1940 (Holmström 1946).

A Mute Swan male and a Whooper Swan female bred unsuccessfully for several years at Lake Ringsjön, southernmost Sweden, before they were successful in 1964 (Seifert 1964). The pair hatched six young, of which three were still alive on $30 \mathrm{Au}-$ gust. The breeding site was situated less than ten kilometres from where the Whooper Swan, after having been gone as a breeding species from south Sweden since 1843 (Wallengren 1849, Gadamer 1852), started to breed in the mid-1940s (Hansson 1968).

In Kalmar, south-eastern Sweden a male and a female Whooper Swan were released in 1960 or 1961 (Jansson 1989). The male soon disappeared, after having been chased by Mute Swans. The female paired up with a Mute Swan male and this mixed pair bred successfully every year 19641967 (Christiansson 1969). In 1968, the Mute Swan male deserted the Whooper Swan female and instead bred successfully with a Mute Swan female (Mathiasson 1992). The Whooper Swan female followed the Mute Swan pair during the summer of 1968 but was alone in the autumn. Breeding of a mixed pair might have occurred during 1969-1973 but not thereafter. There were 13 hybrids in the bays around Kalmar in the autumn of 1967, 10-12 in the 1970s (Mathiasson 1992), no less than 17 in one year (Jansson 1989), seven in 1983 and 1987 (Mathiasson 1992) and hybrids continued to be recorded up to March 1996 (Table 2). Hybrids were seen to pair up, to sit on eggs and to swim around 
Table 1. Number of records of mixed breeding and of observations of non-breeding mixed pairs, mixed families and hybrids where at least one parent species was a swan in countries and regions bordering the Baltic Sea, up to 2010 .

Antalet fynd av häckande blandpar samt av observationer av ickehäckande blandpar, blandfamiljer och hybrider där ätminstone en art var en svan fram till och med 2010 i länder och regioner som gränsar till Östersjön.

\begin{tabular}{llllll}
\hline Country/Region & \multicolumn{2}{l}{$\begin{array}{l}\text { Number of breeding records } \\
\text { Antal häckningsfynd }\end{array}$} & \multicolumn{3}{l}{$\begin{array}{l}\text { Non-breeding observations of } \\
\text { Antal icke häckningsfynd av }\end{array}$} \\
\cline { 2 - 6 } & $\begin{array}{l}\text { attempts } \\
\text { försök }\end{array}$ & $\begin{array}{l}\text { successfull } \\
\text { framgångsrika }\end{array}$ & pairs & families & hybrids \\
& 1 & 6 & 0 & 2 & familjer \\
hybrider
\end{tabular}

with young that seemed to be their own (Jansson 1989). Four second-generation hybrids were with almost full certainty born in 1988 , when a hybrid male paired with a Mute Swan female followed by four young were seen during both the summer and the following winter (Mathiasson 1992). Second-generation hybrids had probably been born in 1983, because three second calendar-year hybrids were seen in February 1984 (Table 2).

In Lake Yxern, south-eastern Sweden, a Mute Swan male and a Whooper Swan female made several breeding attempts during the years up to 1978 (Mathiasson 1979, 1992).

A Whooper Swan male and a Mute Swan female bred at an unknown site in west Sweden in 1991. The breeding was revealed when the pair, together with two young of the year, turned up in Lake Stensjön, Mölndal in December 1991 and they remained at this lake until late April 1992 (Mathiasson 1992). The female had been paired to a Mute Swan in 1989.

One pair, which formed when a Whooper Swan male ousted the Mute Swan male, bred at the coast at Nyhamnsläge, north-eastern Öresund in 2003; five young were seen in late June (Maria Wieloch in litt.), four young 30 June and two young 27 July (Sköldenberg 2003).

In Sweden, there are a couple of breeding records of captive flightless birds, where the offspring were allowed to move around freely (Mathiasson 1979, 1992). In Malmö, a Mute Swan and a Whooper
Swan made breeding attempts in the late 1920s, while a Whooper Swan male and a Mute Swan female hatched a clutch in 1949. One pair produced at least one fledgling in Hudiksvall, Mid-Sweden in the early 1950s. A Mute Swan male and a Whooper Swan female produced four, three, one and two fledglings, respectively, in Skövde, west Sweden during the years 1975-1978, while a similar pair in Borås, also in west Sweden hatched seven young in 1976, of which four remained until 14 April 1977. Known observations of hybrids from the two lastmentioned pairs are summarised in Table 3 .

The three Polish breeding records were quite well separated in space. In the first record, at Lake Wigry in the north-eastern part of the country in 1995, the Mute Swan probably was the male (Sikora 1995), while in the other two, on the Narew old river-bed at Lomża in the north-east in 2003 and at an ox-bow lake on the Obra, near Gorzyca in the north-west in 2004, the Whooper Swan was the male (Baldyga et al. 2003, Maria Wieloch in litt.). Three of the second pair's four young were neckcollared in August and survived at least through December. One of the neck-collared hybrids was reported from Germany in January 2006 as a Mute Swan (Maria Wieloch in litt.).

The list of observations from the non-breeding season contains a mix of birds from cases of both recorded and unrecorded breeding (Table 4). The bird in Stockholm had either been born in captivity or had at least one parent of captive background, 
Table 2. Observations of non-breeding hybrids between Mute Swan Cygnus olor and Whooper Swan Cygnus cygnus at Kalmar, south-eastern Sweden.

Observationer av ickehäckande hybrider mellan knölsvan Cygnus olor och sångsvan Cygnus cygnus vid Kalmar, sydöstra Sverige.

\begin{tabular}{|c|c|c|}
\hline & $\begin{array}{l}\text { Hybrids } \\
\text { Hybrider }\end{array}$ & $\begin{array}{l}\text { Reference Observer } \\
\text { Referens Observatör }\end{array}$ \\
\hline 20 June 1979 & 2 ind & Mathiasson (1992) \\
\hline 29 July 1981 & 1 ind & Peter Sjö \\
\hline 23 May 1982 & ? ind & Peter Sjö \\
\hline 9 February 1984 & $6 \mathrm{ad}+32^{\text {nd }} \mathrm{cy}$ & Peter Sjö \\
\hline 9 February 1984 & 1 ind & Peter Sjö \\
\hline Winter $1987 / 88$ & 3 ind & Per Ålind \\
\hline 18 December 1988 & 4 ind & Per Ålind \\
\hline Spring 1989 & 3 ind & Mathiasson (1992) \\
\hline 7 August 1989 & 1 ind & Lars Lindell \\
\hline 17 August 1989 & $1 \mathrm{ad}$ & Per-Eric Betzholtz \\
\hline Autumn 1989 & 1 ind & Lars Lindell \\
\hline 2 September 1989 & $2 \mathrm{ad}$ & Per-Eric Betzholtz \\
\hline 10 December 1989 & 1 ind & Harald Persson \\
\hline 16 December 1989 & 1 ind & Björn Klevemark \\
\hline Winter 1989/90 & 5 ind & Mathiasson (1992) \\
\hline 6 January 1990 & 1 ind & Archives rrk Småland \\
\hline 10 January 1990 & 1 ind & Per Âlind \\
\hline 15 January 1990 & 2 ind & Archives rrk Småland \\
\hline 17 February 1990 & 1 ind & Per-Eric Betzholtz \\
\hline 20 March 1990 & 1 ind & Per-Eric Betzholtz \\
\hline 26 April 1990 & 1 ind & Per-Eric Betzholtz \\
\hline 4 December 1990 & $1 \mathrm{ad}$ & Björn Klevemark \\
\hline 16 December 1990 & $1 \mathrm{ad}$ & Björn Klevemark \\
\hline 19 January 1991 & $4 \mathrm{ad}$ & Björn Klevemark \\
\hline 11 February 1991 & $4 \mathrm{ad}$ & Björn Klevemark \\
\hline 9 May 1991 & 1 ind & Bruno Helgesson \\
\hline August 1991 & 2 ind & Mathiasson (1992) \\
\hline 10 December 1991 & $1 \mathrm{ad}$ & Björn Klevemark \\
\hline 28 December 1991 & $2 \mathrm{ad}$ & Björn Klevemark \\
\hline Winter 1991/92 & 2 ind & Mathiasson (1992) \\
\hline 14 January 1992 & $3 \mathrm{ad}$ & Per-Eric Betzholtz \\
\hline 30 January 1992 & $2 \mathrm{ad}$ & Per Ålind \\
\hline 26 March 1992 & $1 \mathrm{ad}$ & Per-Eric Betzholtz \\
\hline Autumn 1992 & $1 \mathrm{ad}$ & Per Âlind \\
\hline 15 December 1992 & $1 \mathrm{ad}$ & Björn Klevemark \\
\hline 28 January 1993 & 1 ind & Per-Sture Ljungdahl \\
\hline 1 February 1994 & $1 \mathrm{ad}$ & Björn Klevemark \\
\hline 29 March 1996 & 1 ind & Jan Andersson \\
\hline
\end{tabular}

because the wild Whooper Swan population was very small at that time and restricted to northernmost Fennoscandia (for references, see Boiko \& Kampe-Persson 2010). The hybrids recorded at Torhamn, Karlskrona, Lake Björkerydssjön (all three province of Blekinge) and Västervik (province of Småland) very likely came from Kalmar, just as an undated bird at Färjestaden in the prov- ince of Öland (Anders Waldenström in litt.). The hybrid at Skrunda proved breeding at an unknown site in 2009, and if the pair at River Svēte was its parents, it might have been the first mixed breeding between these two species east of the Baltic Sea. The origin of the hybrid at Fidenäsviken (province of Gotland) is unknown. 
Table 3. Observations of non-breeding hybrids between Mute Swan Cygnus olor and Whooper Swan Cygnus cygnus of presumed captive origin. Two males born in 1976 were neck-collared (1P12 and 1P14) on 20 March 1978 (Mathiasson 1979) and one bird was leg-banded (H6451) on 3 February 1979 (Mathiasson 1992). Sources of observations: 1. Mathiasson (1979), 2. Asplund (1980), 3. Mathiasson (1992) and 4. Ulf Lindell (unpubl.). Observationer av ickehäckande hybrider mellan knölsvan Cygnus olor och sångsvan Cygnus cygnus av förmodad fångenskapsursprung. Två hannar födda 1976 halsringmärktes (1P12 och 1P14) den 20 mars 1978 (Mathiasson 1979) och en fägel ringmärktes (H6451) den 3 februari 1979 (Mathiasson 1992). Källor för observationerna: 1. Mathiasson (1979), 2. Asplund (1980), 3. Mathiasson (1992) och 4. Ulf Lindell (opubl.).

\begin{tabular}{llll}
\hline & $\begin{array}{l}\text { Hybrids } \\
\text { Hybrider }\end{array}$ & $\begin{array}{l}\text { Site } \\
\text { Lokal }\end{array}$ & $\begin{array}{l}\text { Source } \\
\text { Källa }\end{array}$ \\
\hline 18 August-15 September 1976 & $22^{\text {nd }}$ cy & Mullsjön, Hjo, S & 3 \\
16-26 March 1978 & 1 P12 and 1P14 & Ryskärsfjorden, S & 3 \\
28 April 1978 & 1 P14 & Lake Agnestad, S & 1 \\
15-30 September 1978 & $1 \mathrm{P} 14+3$ ind & River Viskan, S & 3 \\
29 November-8 January 1979 & $1 \mathrm{P} 12$ & Kungsbacka, S & 1 \\
2 February 1979 & 1 ind & Instön, Marstrand, S & 1 \\
3 February 1979 & H6451 & Instön, Marstrand, S & 3 \\
2 April 1979 & $1 \mathrm{P} 14$ & Kerteminde, Fyn, Dk & 3 \\
26 April 1979 & $1 \mathrm{P} 12$ & Göteborg, S & 3 \\
3 May 1979 & 1 ind & Stensjön, Mölndal, S & 4 \\
13 May 1979 & 2 ind & Kvinnestadssöö, S & 2 \\
20 September 1979 & H6451 & Stensjön, Mölndal, S & 3 \\
4 December 1979 & 1 ind & Sundsby, Tjörn, S & 3 \\
Winter 1979/80 & 3 ind & River Viskan, S & 3 \\
4 April 1980 & 1 ind & Askimsfjorden, S & 3 \\
6 May 1980 & 1 ind & Asunden, Ulricehamn, S & 3 \\
August early 1980s & 1 ind & Rivöfjorden, Göteborg,S & 3 \\
\hline
\end{tabular}

Table 4. Observations during the non-breeding season of mixed pairs, mixed families and hybrids between Mute Swan Cygnus olor and Whooper Swan Cygnus cygnus in countries and regions bordering the Baltic Sea, up to 2010. Excluded were observations at Kalmar (Table 2) and hybrids of presumed captive origin (Table 3). Two young of the year were neck-collared (1R58 and 1R59) in Poland on 24 August 2003 (Baldyga et al. 2003).

Observationer under ickehäckningstid av blandpar, blandfamiljer och hybrider mellan knölsvan Cygnus olor och sångsvan Cygnus cygnus fram till och med 2010 i länder och regioner gränsande till Östersjön. Uteslöts gjordes observationer vid Kalmar (Tabell 2) och hybrider av förmodat fångenskapsursprung (Tabell 3). Två årsungar halsringmärktes (1R58 och 1R59) i Polen den 24 augusti 2003 (Baldyga mfl 2003).

\begin{tabular}{|c|c|c|c|}
\hline & $\begin{array}{l}\text { Birds } \\
\text { Fåglar }\end{array}$ & $\begin{array}{l}\text { Site } \\
\text { Lokal }\end{array}$ & $\begin{array}{l}\text { Reference Observer(s) } \\
\text { Referens Observatör(er) }\end{array}$ \\
\hline Autumn 1940 & 1 family & Malmö, S & Holmström (1946) \\
\hline 21 Februay 1942 & 1 male & Stockholm, S & Mathiasson (1992) \\
\hline 30 October 1965 & 1 ind & Torhamn, S & Björkvi \& Carlsson (1967) \\
\hline 6 March 1976 & $1 \mathrm{ad}$ & Västervik, S & Mathiasson (1992) \\
\hline 2-27 February 1982 & $2 \mathrm{ad}$ & Karlskrona, S & Svahn (1983) \\
\hline 21 October 1983 & $1 \mathrm{ad}$ & Björkerydssjön, S & Nilsson (1984) \\
\hline $\begin{array}{l}\text { December 1991- } \\
\text { late April } 1992\end{array}$ & 1 family & $\begin{array}{l}\text { Lake Stensjön, } \\
\text { Mölndal, S }\end{array}$ & Mathiasson (1992) \\
\hline 29 April 2001 & $1 \mathrm{ad}$ & Fidenäsviken, S & Per Smitterberg, Bimbi Ollberg \\
\hline January 2006 & 1R58 & Unknown site, D & Maria Wieloch (in litt.) \\
\hline 9 April 2007 & 1 pair & River Svēte, Lv & Hakon Kampe-Persson \\
\hline 4 November 2010 & 12 nd cy & Skrunda, Lv & Dmitrijs Boiko \\
\hline
\end{tabular}


Mute Swan × Black Swan (Chessboard Swan).

One hybrid was seen in Sachsen, Germany in March 1982 (Randler 2001).

\section{Mute Swan $\times$ Greylag Goose (Swoose).}

One pair, the male a Greylag Goose raised by a Mute Swan pair, produced at Staffanstorp, southernmost Sweden one male fledgling in both 1972 and 1975 (Kampe-Persson \& Lerner 2007).

\section{Mute Swan × Greater Canada Goose}

One pair, formed when a Greater Canada Goose male ousted the Mute Swan male, made a breeding attempt in a lake at Egtved, south Jutland, Denmark in 2006 (Kristensen 2006).

\section{Whooper Swan $\times$ Bewick's Swan.}

One pair, the male a Whooper Swan, made a breeding attempt in a disused fishpond in southern Lithuania in May 2010 (Julius Morkūnas in litt.), in the same part of the country as the Bewick's Swan started to breed in 1997 (Stratford 1999, Kurlavičius 2006).

One mixed pair with two young was seen at Lüneburg, north-western Germany in December 2005 (Axel Degen in litt.).

\section{Discussion}

\section{Occurrence}

Even if the hybrids can be identified readily in the field, at least between a Mute Swan and a Black Swan (Randler 2001, 2004), between a Mute Swan male and a Whooper Swan female (Mathiasson 1980a, 1992) and between a swan and a goose (Randler 2001, Amrein 2008, www.gobirding.eu/ Photos/Swoose.php), there are good reasons to assume that the true occurrence is different from the one presented here. There are three main reasons for this discrepancy: lack of observers, lack of interest and misidentifications.

If the mixed pair seen in River Svēte in April 2007 was the same as produced the hybrid seen at Skrunda in November 2010 (Table 4), which seems plausible, there was a period of three and a half year when they were not observed at all. The neckcollared Mute Swan female that bred together with a Whooper Swan male at Nyhamnsläge in 2003 was reported so rarely during the years 2004-2009 (Pelle Andersen-Harild in litt.), that it is impossible to determine if the mixed pair bred also after 2003. The pair might have bred until 2009 but successfully only until 2007 . These examples show that there is a lack of observers also nowadays. It is therefore impossible to get an idea of how many mixed pairs, mixed families and hybrids that remained unobserved.

How often observers have abstained from reporting hybrids and editors abstained from publishing observations of hybrids is for obvious reasons unknown, but has very likely happened more often in areas with the largest numbers of hybrids. In southeastern Sweden, for instance, none of all observations made at Kalmar during the non-breeding seasons 1964/1965-1978/1979 (Mathiasson 1992) is available today, the only observation of a swan hybrid in the province of Öland is undated and unpublished (Anders Waldenström in litt.) and 87\% of the 38 observations listed in Table 2 were earlier unpublished. Moreover, only six out of 29 regional report committees in Sweden replied on inquires about swan hybrids.

In general, hybrids between a Mute Swan male and a Whooper Swan female look like a Whooper Swan (Seifert 1964, Mathiasson 1980b, 1992) while hybrids between a Whooper Swan male and a Mute Swan female look like a Mute Swan, and almost identical as cygnets (Mathiasson 1992). Two of the six young at Ringsjön differed markedly from the others, but these two died young (Seifert 1964). Neck-collared individuals of the firstmentioned type have been reported as Whooper Swans, also by experienced bird-watchers (Mathiasson 1980b), and one neck-collared individual of the second-mentioned type was reported as a Mute Swan (Maria Wieloch in litt.). It is also questionable if all young produced by mixed pairs have been hybrids. The mixed pair in Nyhamnsläge in 2003 formed so late in the season, that the ousted Mute Swan male might have been the father to the young (Sköldenberg 2003). The same might apply also to some other mixed pairs. Extra-pair copulations are rarely recorded in swan species, probably because paired birds co-operate in defending the breeding territory (Rees et al. 1996). Extensive DNA-fingerprinting found no evidence for extra-pair paternity (EPP) in Whooper or Bewick's Swans. Adoptions have been confirmed in all three species however (Rees et al. 1990, Meng \& Parkin 1991). No distinction was made between first- and second-generation hybrids, but if the latter were observed, that was probably the case only at Kalmar in southeastern Sweden.

Taking all factors into consideration, it is likely 
that the true number of breeding mixed pairs, nonbreeding mixed pairs, mixed families and hybrids has been larger than the number of records presented here.

\section{Result of range expansion?}

Just as in this study, hybridisation between a swan and a goose is extremely rare (McCarthy 2006), and it might be that it only occurs after cross-fostering. Cross-fostering during natural conditions can occur either by a pair taking over a nest, where a female already has started to lay (Fabricius 1983) or by brood amalgamation (Eadie et al. 1988, Beauchamp 1998, Randler 2005). Evidences of these behaviours are few from the area covered by this study. In Sweden, there are records of a Mute Swan pair hatching a Greylag Goose egg during two consecutive years, of two pairs of Mute Swan adopting one and two Greylag Goose goslings, respectively, and of a pair of Mute Swan successfully raising a Greylag Goose gosling (Waldenström 2003, Kampe-Persson \& Lerner 2007, Carl Gunnar Gustavsson in litt., Hakon Kampe-Persson own obs.), and in Germany, there are records of eggs of Mute Swan in Greylag Goose nests, of Greylag Goose eggs in Mute Swan nests, and of a Mute Swan pair successfully raising a Greylag Goose gosling (Dittberner \& Dittberner 1976, Hauff 1982, Plath 1985). For hybridisation to occur, however, the cross-fostered bird probably has to be a male, because inter-specific mate choice after false imprinting has been demonstrated only in males (Fabricius 1991). Both the geese in this report were males, the Greylag Goose cross-fostered by Mute Swan while it is unknown how the Greater Canada Goose was brought up.

Two of the breeding records might be explained by one or both mates having a captive background. The Whooper Swan male that bred together with a Mute Swan female somewhere in south Sweden in 1940 had escaped from Pildammsparken in Malmö (Holmström 1946) and the Whooper Swan female that bred together with a Mute Swan male at Kalmar from 1964 onwards had been released at this site in 1960 or 1961 (Jansson 1989). The family that stayed at Stensjön in Mölndal from December 1991 to late April 1992 was very tame, which indicates a captive background. However, as it was possible to come close to also wild birds at that time (Hakon Kampe-Persson own experience), the tameness doesn't prove that any of the mates had a captive background. In Kristianstad, southernmost Sweden a pair of Whooper Swan was kept in cap- tivity since 1934. Almost every year since 1935, the pair produced 5-6 young that were released (Hansson 1968). So, there is a possibility that the Whooper Swan female that bred at Ringsjön in the early 1960s (Seifert 1964) had a captive background, but nothing is known for sure. In all other cases of mixed breeding reported here, nothing is known about the background of the mates. Excluding the two cases involving a goose and the two cases involving swans with captive background, there are eight breeding records in the wild (Table $1)$.

A strong pattern of natal female philopatry and male dispersal is the norm in both swans and geese (Clarke et al. 1997). In the ideal case when range expansion brings breeding ranges of two species in contact with each other, two phases can be discerned. During the first phase only males of the expanding species are found within the breeding range of the other species. During the second phase, when the expanding species just have established itself within the breeding range of the other species, a lack of males in the expanding species' new breeding area might occur. Hybridisation during such conditions is in accordance with the "BestOption-Hypothesis". Instead of giving up breeding altogether, the bird mates with an individual of another species (Hubbs 1955). During the first phase males of the expanding species mate with females of the other species, while during the second phase females of the expanding species mate with males of the other species (Randler 2002). Hybridisation during the first phase is facilitated if males of the expanding species are able to oust males of the other species. That is exactly the case of Whooper Swan in relation to Mute Swan (Dement'ev et al. 1952, Arvidsson 1987).

Seven of the eight breeding records in the wild fit the "Best-Option-Hypothesis", by males of the expanding species hybridising where the expanding species not breed and females of the expanding species hybridising where the expanding species has established a small breeding population (Hansson 1968, Strömblad 1979, Arvidsson 1987, Lindblad \& Löfqvist 1998, Tomiałojć \& Stawarczyk 2003, Kurlavičius 2006, Sikora et al. 2007). The exception is the breeding at Lake Wigry in 1995. However, the identification of the male in that pair was unsure (Sikora 1995). In case the male in that pair was misidentified, the fit is total.

Considering the sizes of the breeding populations of Mute Swan and Whooper Swan around the Baltic Sea hybridisation between these two species is an extremely rare event. That is true even when 
assuming hybridisation to be more common than this compilation shows. And there are no indications that it should become more frequent in the future. But there are good reasons to assume that we can expect finding swan hybrids around the Baltic Sea also in the future. The breeding range of the Whooper Swan is still expanding, especially south of the Baltic Sea, uninterruptedly resulting in new contacts between the breeding ranges of this species and the Mute Swan. Mixed breeding between these two species has, for instance, already been expected in Germany (Schönfeld 1982). In Finland, the breeding ranges of these two species have just come in contact with each other (Markko Loippo in litt.) and in the Leningrad Region, the two species are still separated geographically (Natalia Iovchenko in litt.). The few breeding records of Bewick's Swans in Lithuania might be followed by a true colonisation within parts of the studied area. The species was, for instance, recorded in several squares during the field work for the Latvian Breeding Bird Atlas 2000-2004 (Latvian Ornithological Society unpubl.).

\section{Acknowledgements}

For help with both observations and literature we are indebted to Per Adenäs, Pelle Andersen-Harild, Kenneth Bengtsson, Tobias Berger, Bo Fagerström, Genady Grishanov, Carl Gunnar Gustavsson, Niklas Holmqvist, Natalia Iovchenko, Henning Jensen, Vytautas Jusys, Olof Jönsson, Fredrik Lennartsson, Calle Ljungberg, Markko Loippo, Leho Luigujõe, Lars Lundquist, Ulf Löfås, Stefan Magnusson, Julius Morkūnas, Torben Møller-Nielsen, Leif Nilsson, Åke Nilsson, Lars G Petersson, Kaj Svahn, Anders Waldenström, Maria Wieloch and Staffan Åkeby. Jonas Waldenström gave valuable comments and suggestions on an earlier version of the manuscript. The study was supported by the European Social Fund (to the University of Daugavpils 2009/0140/1DP/1.1.2.1.2/09/IPIA/VIAA/015).

\section{References}

Amrein, M. 2008. Wenn der Schwan mit der Gans. Der Bund, 11 April 2008: 31.

Andersson, Å., Madsen, J., Mooij, J. \& Reitan, O. 1999. Canada Goose Branta canadensis: Fennoscandia/continental Europe. Pp. 236-245 in Goose Populations of the Western Palearctic. (Madsen, J., Cracknell, G. \& Fox, T., eds.). Wetlands International Publ. No. 48. Wetlands International \& National Environmental Research Institute, Wageningen \& Rønde.

Arvidsson, B.L. 1987. Distribution and population size of
Whooper Swan, Cygnus cygnus, in Sweden. Vår Fågelvärld 46: 248-255. (Swedish with English summary).

Asplund, G. 1980. Två hybridsvanar observerade i Kvinnestadsjön, Vårgårda. Gavia 6: 18.

Baldyga, T., Wieloch, M. \& Czyż, S. 2003. Second mixed brood of Whooper Swan Cygnus cygnus and Mute Swan C. olor in Poland. Notatki Ornitologiczne 44: 270-273. (Polish with English summary).

Beauchamp, G. 1998. The relationship between intra- and interspecific brood amalgamation in waterfowl. Condor 100: 153-162.

Björkvi, S. \& Carlsson, C.-I. 1967 En korsning mellan knöloch sångsvan (Cygnus cygnus $\times$ olor $)$ sedd vid Torhamn. Fåglar i Blekinge 3: 31 .

Boiko, D. \& Kampe-Persson, H. 2010. Breeding Whooper Swans Cygnus cygnus in Latvia, 1973-2009. Wildfowl 60: 168-177.

Brazil, M. 2003. The Whooper Swan. T. \& A.D. Poyser, London.

Christiansson, G. 1969. Fågelrapport från sydöstra Småland och Öland 1965-1967. Vår Fågelvärld 28: 57-62.

Clarke, A.L., Sæther, B.-E. \& Røskaft, E. 1997. Sex biases in avian dispersal: a reappraisal. Oikos 79: 429-438.

Dement'ev, G.P., Gladkov, N.A., Isakov, Yu.A., Kartashev, N.N., Kirikov, S.V., Mikheev, A.V. \& Ptushenko, E.S. 1952. Ptitsy Sovetskogo Soyuza. Vol. IV. Soviet Science Publishing House, Moscow.

Dittberner, H. \& Dittberner, W. 1976. Ein Mischgelege von Höckerschwan (Cygnus olor) and Graugans (Anser anser). Beiträge zur Vogelkunde 22: 367-368.

Eadie, J.McA., Kehoe, F.P. \& Nudds, T.D. 1988. Pre-hatch and post-hatch brood amalgamation in North American Anatidae: a review of hypotheses. Canadian Journal of Zoology 66: 1709-1721.

Fabricius, E. 1983. The Canada Goose in Sweden. PM 1678. Statens Naturvårdsverk, Stockholm. (Swedish with English summary).

Fabricius, E. 1991. Interspecific Mate Choice Following Cross-fostering in a Mixed Colony of Greylag Geese (Anser anser) and Canada Geese (Branta canadensis). A Study on Development and Persistence of Species Preferences. Ethology 88: 287-296.

Fog, M. 1973. Kanadensisk gås i Europa. Vildtbiologisk Station, Kalø.

Gadamer, H. 1852. Angabe der im nordöstlichen Schonen vorkommenden Vögel mit besonderer Rücksicht auf die hier brütenden. Naumannia 2(3): 1-19.

Hansson, L. 1968. Sångsvanen som skånsk häckfågel. Meddelanden från Skånes Ornitologiska Förening 7: 45-50.

Hauff, P. 1982. Bestandsentwicklung und Brutbiologie der Graugans, Anser anser, im NSG Kuhlrader Moor under Röggeliner See. Beiträge zur Vogelkunde 28: 48-58.

Holmström, C.T. (ed.) 1946. Våra Fåglar i Norden. Natur och Kultur, Stockholm.

Hubbs, C.L. 1955. Hybridization between fish species in nature. Systematic Zoology 4: 1-20.

Jansson, T. 1989. Knångsvanen - Kalmars egen "fula ankunge". Fåglar i Östra Småland 1: 5-6.

Kampe-Persson, H. 2002. Anser anser Greylag Goose. BWP Update 4: 181-216.

Kampe-Persson, H. 2010. Naturalised geese in Europe. Ornis Svecica 20: 155-173.

Kampe-Persson, H. \& Lerner, H. 2007. Occurrence of hybrid 
geese in Sweden - a conservation problem? Ornis Svecica 17: $154-186$.

Kristensen, H. 2006. Partnerbytte i andedammen. Joeger 15(12): 66.

Kurlavičius, P. (ed.) 2006. Lithuanian breeding bird atlas. Lutute, Kaunas. (Lithuanian with English summary).

Lindblad, T. \& Löfqvist, C. 1998. Breeding Whooper Swans Cygnus cygnus in Scania in 1997. Anser 37: 153-160. (Swedish with English summary).

Mathiasson, S. 1979. Svanar som individer - i familj och ensamma. Fåglar på Västkusten 13: 7-13.

Mathiasson, S. 1980a. Knölsvanen - prydnadsfågel eller villebråd? Svensk Jakt 118: 46-49.

Mathiasson, S. 1980b. Två hybridsvanar observerade i Kvinnestadsjön, Vårgårda. Gavia 6: 19.

Mathiasson, S. 1992. Hybrider mellan knölsvan och sångsvan. Arstryck Göteborgs Naturhistoriska museum 1992: 43-59. (Swedish with English summary).

McCarthy, E.M. 2006. Handbook of avian hybrids of the world. Oxford University Press, Oxford.

Meng, A. \& Parkin, D.T. 1991. Alloparental behaviour in Mute Swans Cygnus olor detected by DNA finger-printing. In Proceedings of the Third IWRB International Swan Symposium (Sears, J. \& Bacon, P.J., eds.), Oxford 1989. Wildfowl, Supplement 1: 310-318.

Nilsson, T. 1984. Fågelrapport för 1983. Fåglar i Blekinge 20: 82-132.

Plath, L. 1985. Ein Mischgelege von Graugans (Anser anser) und Höckerschwan (Cygnus olor). Beiträge zur Vogelkunde 31: 170-171.

Randler, C. 2000. Hybrid wildfowl (Anseriformes) in Western Central Europe - distribution, occurrence and causes. Ökologie der Vögel / Ecology of Birds 22: 1-106. (German with English summary).

Randler, C. 2001. Field identification of hybrid wildfowl geese. Alula 7: 42-48.

Randler, C. 2002. Avian hybridization, mixed pairing and female choice. Animal Behaviour 63: 103-119.

Randler, C. 2004. Frequency of bird hybrids: does detectability make all the difference? Journal of Ornithology 145: 123-128.

Randler, C. 2005. Do forced extrapair copulations and interspecific brood amalgamation facilitate natural hybridisation in wildfowl? Behaviour 142: 477-488.

Rees, E.C., Bowler, J.M. \& Butler, L. 1990. Bewick's and Whooper Swans: the 1989-90 season. Wildfowl 41: 176181.

Rees, E.C., Lievesley, P., Pettifor, R.A. \& Perrins, C. 1996. Mate fidelity in swans: an interspecific comparison. Pp. 118-137 in Partnerships in Birds. (Black, J.M., ed.). Oxford University Press, Oxford.

Scherer, S. \& Hilsberg, T. 1982. Hybridisation and relationship in the Anatidae - a taxonomic and evolutionary consideration. Journal für Ornithologie 123: 357-380. (German with English summary).

Schönfeld, M. 1982. Beitrag zur Biologie der Schwäne. Falke 29: 205-206.

Seifert, B. 1964. Svanbastarder i Ringsjön. Meddelanden från Skånes Ornitologiska Förening 3: 44.

Sikora, A. 1995. Mixed brood of the whooper swan (Cygnus cygnus) and mute swan (Cygnus olor) in the province of Suwlki. Notatki Ornitologiczne 36: 368-370. (Polish with English summary).
Sikora, A., Rohde, Z., Gromadzki, M., Neubauer, G. \& Chylarecki, P. (eds.) 2007. The atlas of breeding birds in Poland 1985-2004. Bogucki Wydawnictwo Naukowe, Poznan. (Polish with English summary).

Sköldenberg, J. 2003. Märklig svanhäckning. www.skof.se.

Stratford, J. 1999. Ornithological fauna of Baltoji Vokè, an important bird area. Acta Zoological Lituanica 9(3): 24-79.

Strömblad, W. 1979. Sångsvanen i Småland. Bubo 1979: 9-19.

Svahn, G. 1983. Fågelåret 1982. Fåglar i Blekinge 19: 147163.

Svensson, S., Svensson, M. \& Tjernberg, M. 1999. Svensk fågelatlas. Vår Fågelvärld, supplement 31, Stockholm.

Tomiałojć, L. \& Stawarczyk, T. 2003. The avifauna of Poland. Distribrution, numbers and trends. Vol. 1. Polskie Towarzystwo Przyjaciół Przyrody "pro Natura", Wrocław. (Polish with English summary).

Waldenström, A. 2003. Inventering av Dröstorpsmossen 2002. Calidris 32: 26-31.

Wallengren, H.D.J. 1849. Foglar i nordöstra Skåne. Öfversigt af Kongliga Vetenskaps-Akademiens Förhandlingar, Stockholm.

Wieloch, M., Włodarczyk, R. \& Czapulak, A. 2004. Cygnus olor Mute Swan. BWP Update 6: 1-38.

\section{Sammanfattning}

Under det senaste halvseklet har flertalet svan- och gåsarter ökat stort $\mathrm{i}$ både individantal och $\mathrm{i}$ geografisk utbredning runt Östersjön. Från att under tidigt 1950-tal ha räknat endast några tiotal par och varit begränsad till nordligaste Sverige och Finland häckar sångsvanen idag i alla länder och regioner som gränsar till Östersjön och antalet häckande par uppgår idag till cirka 10.000. Från ett kärnområde i sydöstra Sverige har kanadagåsen ökat på ett liknande sätt som sångsvanen, även om den inte häckar i Baltikum eller västligaste Ryssland, och ökat från 150 par 1960 till 23.000-30.000 par idag. Också grågåsen har ökat kraftigt i antal och utbredning under de senaste 50 åren, medan ökningen i antal och utbredning varit mindre uttalad hos knölsvanen. Den vitkindade gåsen och den mindre sångsvanen däremot började häcka inom studieområdet först på 1950-talet respektive 1990-talet.

Ökningarna i geografisk utbredning har resulterat i fler kontakter mellan fåglar av närstående arter, vilket i sin tur gynnat blandhäckningar. Hybridisering är betydligt vanligare inom Anatidae än inom andra fågelgrupper, men sällsynt bland svanar. Eftersom fåglar med fångenskapsbakgrund är mer benägna att hybridisera, måste även fåglarnas ursprung tas i beaktande. Kanadagåsen är medvetet införd, återupprättandet av grågåsens häckningsutbredning gynnades av ett flertal lokala utsättningar, framförallt i Sverige och Tyskland, häckpopulatio- 
nen av vitkindad gås i Östersjöområdet har med största sannolikhet uppstått som resultat av frisläppande och rymningar från fångenskap, och också sångsvanens spridning gynnades av utsättningar, till exempel i Jämtland och Hälsingland.

Inom ett område omfattande Sverige, Finland, Leningradregionen, Estland, Lettland, Litauen, Kaliningradregionen, Polen, Tyskland och Danmark fann vi totalt 12 blandhäckningar, i vilka åtminstone den ena arten var en svan. Det rörde sig om sju fynd i Sverige, tre i Polen samt ett vardera i Litauen och Danmark. Nio fall utgjordes av knölsvan $\times$ sångsvan samt ett vardera av knölsvan $\times$ grågås, knölsvan $\times$ kanadagås och sångsvan $\times$ mindre sångsvan. Observationer under ickehäckningstid av blandfamiljer och hybrider avslöjade dessutom ett antal ytterligare fall av blandhäckningar.

Den första kända häckningen av knölsvan $\times$ sångsvan skedde på okänd ort i Sydsverige, och avslöjades då sångsvanhanen dök upp i Pilsammsparken i Malmö, varifrån han hade rymt, med en unge hösten 1940. En knölsvanhane och en sångsvanhona genomförde ett flertal häckningsförsök vid Ringsjön i Skåne innan de var framgångsrika 1964. En utsatt sångsvanhona häckade framgångsrikt i par med en knölsvanhane i Kalmar åren 1964 1967, kanske även senare. Som mest sågs det ett år 17 hybrider, lokalt kallade knångsvanar, av olika ålder i Kalmartrakten och observationer av hybrider gjordes fram till och med mars 1996. En knölsvanhane och en sångsvanhona gjorde ett flertal häckningsförsök i småländska Yxern fram till och med 1978, medan en sångsvanhane och en knölsvanhane häckade på okänd ort i Västsverige 1991. Häckningen avslöjades då paret dök upp med 2 ungar i Stensjön, Mölndal i december 1991. Den senast kända häckningen i Sverige skedde i skånska Nyhamnsläge 2003, sedan en sångsvanhane efter en flera dagar lång kamp jagat bort knölsvanhanen. Enda kända häckningsförsöket av sångsvan × mindre sångsvan skedde 2010 i närheten av den lokal där den mindre sångsvanen började häcka i Litauen 1997. Redan i december 2005 sågs dock en blandfamilj med 2 ungar vid Lüneburg i Tyskland, dock av okänt ursprung.

Blandhäckning mellan svan och gås är extremt sällsynt och det kan mycket väl vara så att det endast förekommer efter det att en gås haft svanar som fosterföräldrar, samt att gåsen är en hane. De två här beskrivna fallen motsäger åtminstone inte detta.

Hos såväl svanar som gäss är honorna lokaltrogna medan hanarna sprider sig. Generellt när två arter kommer i kontakt med varandra kan därför två skeden urskiljas. I det första skedet återfinns endast hanar av den expanderande arten inom den andra artens häckningsområde. I det andra skedet, när den expanderande arten just etablerat sig inom den andra artens häckningsområde, kan det uppstå brist på hanar i den nyetablerade häckpopulationen. Hybridisering i dessa båda situationer stämmer överens med "Best-Option-Hypothesis", där den enskilda fågeln gör det bästa av situationen och bildar par med en annan art när artfränder saknas. Om vi räknar bort de båda fallen av hybridisering mellan svan och gås samt de båda fallen med åtminstone en fågel med fångensskapsbakgrund (Malmö och Kalmar) återstår åtta häckningsfynd i det vilda. Sju av dessa stämmer in på denna hypotes. Undantaget är häckningen vid sjön Wigra 1995. I det fallet rådde dock osäkerhet om vilken av arterna som var hane. Om hanen felbestämts i det fallet blir överrensstämmelsen fullständig.

Med tanke på det stora antalet häckande knölsvanar och sångsvanar runt Östersjön förekommer hybridisering dem emellan mycket sällsynt. Och det finns inget som talar för att det kommer bli mer frekvent i framtiden. Däremot kan vi nog förvänta oss hybrider även framöver. Sångsvanen expanderar fortfarande, vilket ständigt leder till nya kontakter mellan denna art och knölsvan. Dessutom är det inte otänkbart att den mindre sångsvanen etablerar sig på allvar inom det studerade området. Till exempel återfanns arten i ett flertal rutor i samband med fältarbetet för den andra lettiska häckfågelatlasen. 